\title{
EFFECT OF SORBENT REACTIVITY ON FLUE GAS DESULPHURIZATION IN FLUIDIZED-BED BOILERS UNDER AIR FIRING MODE
}

\author{
Arkadiusz Szymanek, ${ }^{2}$ Margarita de las Obras-Loscertales ${ }^{3}$ and Anna Pajdak ${ }^{1 *}$ \\ 1. The Strata Mechanics Research Institute of the Polish Academy of Sciences, Reymonta 27, 30-059 Cracow, Poland \\ 2. Institute of Thermal Machinery, Częstochowa University of Technology, Armii Krajowej 21, 42-201 Czestochowa, Poland \\ 3. Department of Energy and Environment, Instituto de Carboquímica (ICB-CSIC), Miguel Luesma Castan, 4, 50018 Zaragoza, Spain
}

\begin{abstract}
The article presents research into the reactivity and $\mathrm{SO}_{2}$ sorption abilities of calcareous sorbents, which vary in quality. Two sorbents were used: limestone and travertine, with grain sizes between 0.125 and $0.250 \mathrm{~mm}$. The sorbent reactivity tests were performed on a laboratory test stand. The reactivity index and the conversion degree were also determined. $\mathrm{SO}_{2}$ sorption studies were conducted in an industrial boiler. The desulphurization efficiency was determined taking into the account the content of calcium and sulphur put into and taken out of the boiler. The relation of the desulphurization process parameters such as fuel sulphur content, stream sorbent, sorbent utilization degree, desulphurization efficiency, depending on the molar ratio $\mathrm{Ca} / \mathrm{S}$ and the duration of the process was specified. The $\mathrm{SO}_{2}$ sorption results were compared with the reactivity index of the sorbents. The investigation in dry combustion-gas desulphurization methods showed the high quality of the sorbents whose reactivity index is above 3.5 .
\end{abstract}

Keywords: fluidized bed combustion, sorbent reactivity, desulphurization process

\section{INTRODUCTION}

$\mathrm{T}$ The emission of pollutant gases into the atmosphere from fossil fuel combustion such as coal in large combustion plants causes important environmental problems. So, during the combustion process, the sulphur from coal is oxidized to $\mathrm{SO}_{2}$ and released into the atmosphere contributing to acid rain formation.

Among the possibilities for burning coal, fluidized bed combustors are a promising technolog $y^{[1-6]}$ because the desulphurization process (up to $95 \%$ ) can be carried out by injecting calcium-based sorbent into the furnace.

According to the equilibrium diagram of $\mathrm{CaCO}_{3}-\mathrm{CaO}$, under typical air firing mode, $\mathrm{CaO}$ reacts with $\mathrm{SO}_{2}$ to form $\mathrm{CaSO}_{4}$ (solid). The reactions that take place in the desulphurization process are:

$\mathrm{CaCO}_{3} \rightarrow \mathrm{CaO}+\mathrm{CO}_{2}$

$2 \mathrm{CaO}+2 \mathrm{SO}_{2}+\mathrm{O}_{2} \rightarrow 2 \mathrm{CaSO}_{4}$

The more usual setup used to analyze the effect of main operating conditions on the limestone behaviour were thermogravimetric analyzers (TGA) ${ }^{[7-9]}$ and bench fluidized bed reactors. ${ }^{[10,11]}$ The former allows studying the behaviour of the limestone for long time tests, simulating the mean residence time existing in a fluidized bed combustor, and the latter makes it possible to study the limestone sulphation in similar operating conditions to those in fluidized bed boilers. As well as the operating conditions, such as temperature, particle size, $\mathrm{SO}_{2}$ concentration, attrition, ${ }^{[12-14]}$ etc., the quality of sorbent ${ }^{[15]}$ is the basic parameter that determines the effects of dry flue gas desulphurization methods. The effects should be understood not only as the meeting of required sulphur dioxide concentration levels, but also the minimizing of the streams of sorbents used and the improvement of the quality of products after flue gas desulphurization (reduction of free $\mathrm{CaO}$ ). Presently, quite sufficient attention is only being given to the efficiency of flue gas desulphurization. However, it should be borne in mind that the lowering of permissible emission levels will entail a considerable increase in the amounts of sorbents needed for flue gas desulphurization, and the only way of meeting the newly specified emission levels will be either by selection of the best limestones for flue gas desulphurization or improving their sorption properties.

Based on previous studies on reactivity index carried out over a period of 15 years (with more than 1200 analyses of sorbents from different deposits being made) it can be stated that good class sorbents predominate (over $60 \%$ of results) in flue gas desulphurization. A mere $4 \%$ of the sorbents examined fit in the class of excellent sorbents and $15 \%$ in the very good sorbent class, the rest being made up by sorbents of either sufficient or poor quality. ${ }^{[16-26]}$

The aim of this work was to analyze the behaviour of two limestones with different sorption properties and reactivity indexes, on the flue gas desulphurization process. For this purpose, experimental tests in a lab-stand and in an industrial plant of fluidized bed boiler were performed.

\section{EXPERIMENTAL}

\section{Materials}

To study the effect of the reactivity of the limestone on the flue gas desulphurization, two sorbents were used in a narrow range of

\footnotetext{
* Author to whom correspondence may be addressed. E-mail address: pajdak@img-pan.krakow.pl

Can. J. Chem. Eng. 96:895-902, 2018

(C) 2017 Canadian Society for Chemical Engineering DOI 10.1002/cjce.23012

Published online 8 October 2017 in Wiley Online Library

(wileyonlinelibrary.com).
} 


\begin{tabular}{lcccccc}
\multicolumn{7}{l}{ Table 1. Chemical composition of the limestones } \\
\hline & $\mathrm{CaCO}_{3}$ & $\mathrm{MgCO}_{3}$ & $\mathrm{SiO}_{2}$ & $\mathrm{Al}_{2} \mathrm{O}_{3}$ & $\mathrm{Fe}_{2} \mathrm{O}_{3}$ & Other \\
\hline $\begin{array}{l}\text { Unit } \\
\text { Limestone } \\
\text { (sorbent I) }\end{array}$ & 91.10 & 0.75 & 1.54 & 0.77 & 0.12 & 5.72 \\
$\begin{array}{c}\text { Travertine } \\
\text { (sorbent II) }\end{array}$ & 97.20 & 0.10 & 0.20 & 0.50 & 0.10 & 1.90 \\
\hline
\end{tabular}

particle size between 0.125 and $0.250 \mathrm{~mm}$. However, in the case of sorbents of a particle size below $0.125 \mathrm{~mm}$, the material was tested within the entire particle size range. Table 1 shows the chemical composition of both limestones which exhibit a high $\mathrm{CaCO}_{3}$ content. In addition, brown coal with a particle size between 0.05 and $0.30 \mathrm{~mm}$ was used as fuel whose ultimate and proximate analysis is shown in the Table 2 .

\section{Procedure}

To study the behaviour of the sorbents, two facilities were used: a laboratory test stand and an industrial fluidized bed boiler.

\section{Laboratory test stand}

The tests were carried out on a laboratory test stand whose scheme is shown in Figure 1.

The facility consists of an electric furnace and a quartz reactor. The reactor has a diameter of $0.1 \mathrm{~m}$ and a height of $1.5 \mathrm{~m}$. Sorbents and the model gas containing sulphur dioxide, oxygen, nitrogen, and carbon dioxide were fed into the column. The temperature in the reaction chamber was kept at a constant level of $378 \mathrm{~K}$ for the drying stage and $1123 \mathrm{~K}$ for calcination and for sorption property tests. The flow of sulphur dioxide was controlled using a double control system consisting of a regulator coupled with a rotameter and a mass flow controller. The flow of the remaining gases was controlled and regulated by the use of regulators and rotameters. The concentrations of individual gas components at the column outlet were also measured using a SICK Maihak type Mulror 610 flue gas analyser (Germany). In each sample tested, the chemical composition was determined. Using a LECO SC-144 analyzer (Poland), the contents of sulphur were determined. Using the classic chemical method, ${ }^{[30]}$ the percentage of $\mathrm{Ca}^{2+}$ content was determined. The test proper was conducted in two steps. In the first step, the sample was calcined at a temperature of $1123 \mathrm{~K}$ for $0.5 \mathrm{~h}$ in a nitrogen atmosphere. In the second step, the remaining model gases, composed of $\mathrm{SO}_{2}-5091 \mathrm{mg} \cdot \mathrm{m}^{-3}, \mathrm{CO}_{2} 16 \%$, and $\mathrm{O}_{2} 3 \%$ with the balance of nitrogen carrier gas, were fed into the calcined sample. The

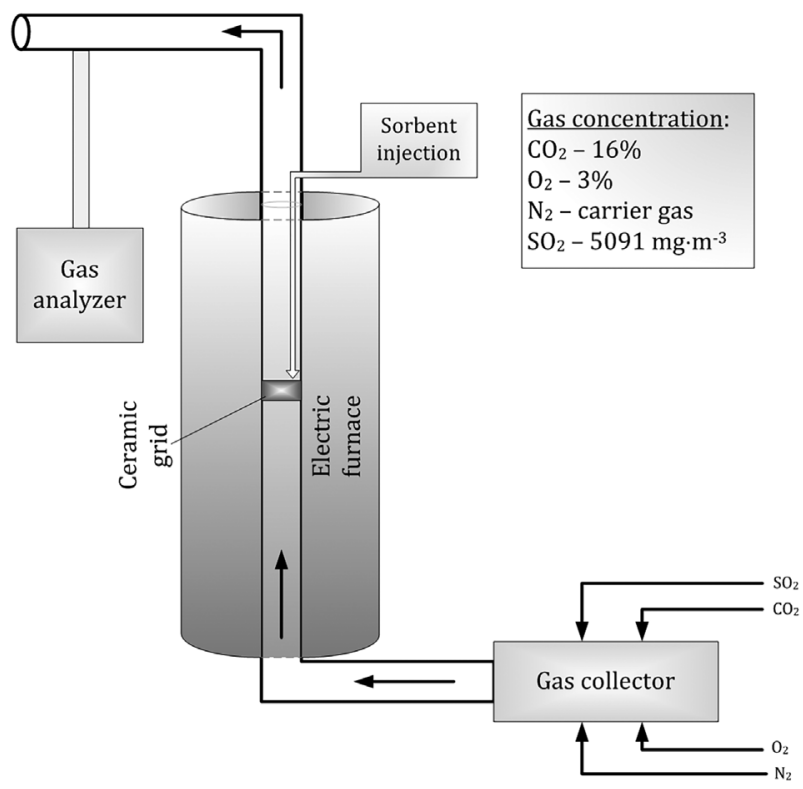

Figure 1. Test stand for testing the reactivity and absolute sorption and the conversion degree, based on Walawska et al. ${ }^{[29]}$

second step took $1.5 \mathrm{~h}$. After completion of the test, chemical composition of the flue gas desulphurization product was tested. Using the TruSpec CHN analyzer (Poland), the contents of carbon, hydrogen, and nitrogen were assayed. The concentration of oxygen was determined from the difference.

To study the sorption properties, the absolute sorption and reactivity index were determined based on the Ahlstrom Pyropower Development Laboratory test ${ }^{[15]}$ and using Equations (3) and (4). For the assessment of the sorption properties, the reactivity scale shown in Table 3 was used.

$$
\begin{aligned}
& R_{i}=\frac{\frac{x_{C a}}{100} \cdot \frac{M_{S}}{M_{C a}} \cdot\left(1-\frac{M_{C_{2}}}{M_{\mathrm{C}}} \cdot \frac{x_{C_{p}}}{100}-\frac{M_{S O_{2}}}{M_{S}} \cdot \frac{x_{S_{p}}}{100}\right)}{\frac{x_{S_{p}}-x_{S_{b}}}{100}+\frac{M_{\mathrm{CO}_{2}}}{M_{C}} \cdot\left(\frac{x_{C_{p}} \cdot x_{S_{b}}-x_{C_{b}} \cdot x_{S_{p}}}{10000}\right)}, \\
& C_{i}=\frac{1000 \cdot\left[\frac{x_{S_{p}}-x_{S_{b}}}{100}+\frac{M_{\mathrm{CO}_{2}}}{M_{C}} \cdot\left(\frac{x_{C_{p}} \cdot x_{S_{b}}-x_{C_{b}} \cdot x_{S_{p}}}{10000}\right)\right]}{1-\frac{M_{\mathrm{CO}_{2}}}{M_{C}} \cdot \frac{x_{C_{p}}}{100}-\frac{M_{S_{O_{2}}}}{M_{S}} \cdot \frac{x_{S_{p}}}{100}} .
\end{aligned}
$$

The conversion degree was determined based on the variations in sulphur dioxide concentration during the test and the initial concentration, when a load of sorbent, calcium oxide, of $1.5 \mathrm{~g}$ was

\begin{tabular}{|c|c|c|c|}
\hline \multicolumn{4}{|c|}{ Brown coal } \\
\hline \multicolumn{2}{|c|}{ Technical analysis $\left(\mathrm{g} \cdot \mathrm{g}^{-1}\right)(\mathrm{ad})$} & \multicolumn{2}{|c|}{ Elemental analysis $\left(\mathrm{g} \cdot \mathrm{g}^{-1}\right)(\mathrm{ad})$} \\
\hline Moisture $\left(g \cdot g^{-1}\right)$ & 45 & Carbon content (C) (\%) & 39.5 \\
\hline Volatile matter $\left(\mathrm{V}^{\text {daf }}\right)\left(\mathrm{g} \cdot \mathrm{g}^{-1}\right)$ & 35 & Hydrogen content $(\mathrm{H})(\%)$ & 2.6 \\
\hline Coke residue $\left(F C^{\text {diff }}\right)\left(g \cdot \mathrm{g}^{-1}\right)$ & 5 & Oxygen content $\left(\mathrm{O}^{\text {diff }}\right)(\%)$ & 12.0 \\
\hline Ash $\left(g \cdot g^{-1}\right)$ & 15 & Sulphur content (S) (\%) & 0.8 \\
\hline Lower heating value $\mathrm{LHV}\left(\mathrm{kJ} \cdot \mathrm{kg}^{-1}\right)$ & 11500 & Nitrogen content $(\mathrm{N})(\%)$ & 0.9 \\
\hline
\end{tabular}

Table 2. Technical and elemental analysis of the fuel

Parameters determined according to Polish standards ${ }^{[27-28]}$

Superscript: daf-dry and ashless state; diff-calculated by difference

ad - on an air dried basis 


\begin{tabular}{lcc}
\hline \multicolumn{3}{l}{ Table 3. Scale of the reactivity of sorbents ${ }^{[15]}$} \\
\hline Limestone assessment & $\mathrm{R}_{\mathrm{i}}$ & $\mathrm{C}_{\mathrm{i}}$ \\
\hline Excellent & $<2.5$ & $>120$ \\
Very good & $2.5-3.0$ & $100-20$ \\
Good & $3.0-4.0$ & $80-100$ \\
Satisfactory & $4.0-5.0$ & $60-80$ \\
Poor & $>5.0$ & $<60$ \\
\hline
\end{tabular}

fed into the reaction column. The velocity of the gas was $1.25 \mathrm{~m} \cdot \mathrm{s}^{-1}$. Calcium oxide from the limestone was assayed in chemical analysis prior to the test. ${ }^{[31]}$ The calculation was made following Equation (5):

$X=\frac{V_{S} \cdot R \cdot T}{w \cdot P} \int_{0}^{t}\left(c_{0}-c_{t}\right) d t$.

\section{Industrial boiler}

Another facility used for the analysis of the flue gas desulphurization process was a circulating fluidized bed combustor. The assessment of the flue gas desulphurization process was based on the balance of calcium in the combustion chamber. The sorbent used for the desulphurization process met the requirements of the particle size curve for the fluidized bed boiler with a range of particle size between 0.09 and $0.30 \mathrm{~mm}$. The balance enabled the determination of the actual limestone consumption. A block diagram of the developed calcium balance is shown in Figure 2 .

The balance was based on the basic principle saying that the amount of calcium fed into the boiler equals the amount of calcium removed from the boiler, represented by Equation (6):

$m_{C a_{\text {Fed }}}=m_{C a_{\text {Rem }}}$.

The streams of calcium fed into and removed from the boiler, occurring in Equation (6), were defined according to the following relationships:

$m_{C a_{F e d}}=\gamma_{C a_{F}} \cdot m_{F}+\gamma_{C a_{S o r b}} \cdot m_{S o r b}$,
$m_{C a_{\text {Rem }}}=\gamma_{C a_{F A}} \cdot m_{F A}+\gamma_{C a_{B A}} \cdot m_{B A}$.

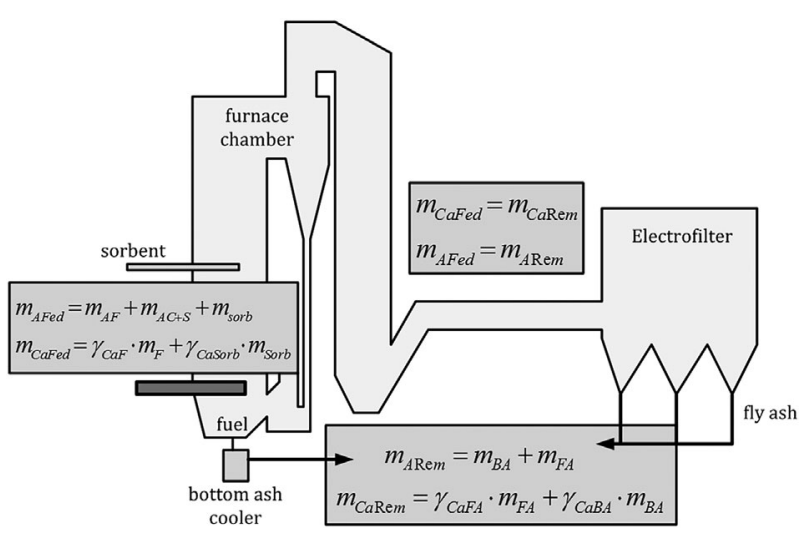

Figure 2. Diagram of balance calculation, based on Czakiert et al. ${ }^{[32]}$
In the stream of calcium fed into the boiler, the calcium introduced with the flue gas desulphurization sorbent and the calcium introduced with the fuel are considered. As the test results show, calcium contained in brown coal accounts for as much as up to $7 \%$ of the calcium supplied for desulphurization, so this makes a significant figure in the flue gas desulphurization process. In the case of hard coal, these values were smaller even by an order of magnitude.

The efficiency of the sulphur bonding process was calculated based on the obtained average $\mathrm{SO}_{2}$ concentration in the flue gas and the calculated $\mathrm{SO}_{2}$ concentration, assuming $100 \%$ conversion of $\mathrm{S}$ to $\mathrm{SO}_{2}$, according to the relationship below:

$\eta=\frac{C_{\mathrm{TSO}_{2}}-C_{\mathrm{SO}_{2}}}{C_{\mathrm{TSO}_{2}}}$

A very important element in the assessment of flue gas desulphurization is the coefficient of calcium utilization for flue gas desulphurization purposes, which is determined from Equation (10):

$\frac{S}{C a}=\frac{\eta \cdot m_{F} \cdot \gamma_{S_{F}}}{m_{F} \cdot \gamma_{C a_{F}}+m_{S o r b} \cdot \gamma_{C a_{S o r b}}}$

The Ca/S molar ratio is determined from Equation (11). This ratio represents the amount of sorbent and fuel calcium used for desulphurization related to the amount of fuel sulphur:

$\frac{C a_{T}}{S}=\frac{0.32 \cdot m_{\mathrm{Sorb}} \cdot \gamma_{\mathrm{CaCO}_{3} \text { Sorb }}+0.57 \cdot m_{F} \cdot \gamma_{\mathrm{CaO}_{F}}}{m_{F} \cdot \gamma_{S_{F}}}$

The adopted methodology involved carrying out tests with $4 \mathrm{~h}$ breaks. During that time, between the measurements, the following aspects stabilized: the process parameters, the flow in the boiler, as well as the equilibrium of the calcium in the fly ash and the bottom ash. In the case of mechanical activation, samples of fly ash for activation and samples of semi-dry flue gas desulphurization product were additionally taken. The sampling time was determined by the time necessary for boiler stabilization at specific parameters and the technical capabilities to take all samples at the same time. A period of $72 \mathrm{~h}$ was assumed as the minimum time of boiler operation at constant parameters. During the test, a constant boiler power was maintained to assure the comparability of the obtained results. The second constant parameter was sulphur dioxide concentration at the exit of the combustor (around $400 \mathrm{mg} \cdot \mathrm{m}^{-3}$ ). It was maintained at a fixed level during testing, and controlled at the outlet from the combustion chamber and from the flue. Measurements were taken using a monitoring system coupled with the boiler's system. The scope of tests for particular samples is given in Table 4. Due to the fact that the fuel parameters were variable during testing, the

\begin{tabular}{|c|c|}
\hline Fly ash & $\mathrm{CaO}_{\text {free, }}, \mathrm{CaO}_{\text {total }}, \mathrm{CaCO}_{3}, \mathrm{~S}_{\text {total, }}, \mathrm{C}_{\text {total }}, \mathrm{C}_{\text {carbonate }}$ \\
\hline Bottom ash & $\mathrm{CaO}_{\text {free, }}, \mathrm{CaO}_{\text {total}}, \mathrm{CaCO}_{3}, \mathrm{~S}_{\text {total }}, \mathrm{C}_{\text {total }}, \mathrm{C}_{\text {carbonate }}$ \\
\hline Sorbent & $\begin{array}{l}\mathrm{CaCO}_{3}, \mathrm{MgCO}_{3}, \mathrm{~S}_{\text {total}} \text {, loss on ignition, moisture } \\
\text { content, } \mathrm{Ri}, \mathrm{Ci}, \mathrm{X}\end{array}$ \\
\hline Fuel & $\begin{array}{l}\text { Calorific value, ash content, moisture content, } \mathrm{C}, \mathrm{S}, \mathrm{O} \text {, } \\
\mathrm{N}, \mathrm{H} \text {, and } \mathrm{Ca} \text { contents }\end{array}$ \\
\hline
\end{tabular}


balance was made using data averaged over the whole measurement day.

The analyses of the physicochemical properties of samples were made based on the applicable standards. ${ }^{[27,28,33-40]}$ The determination of the carbon and sulphur contents of sorbent, fuel, fly ash, and bottom ash was made using a LECO SC-144 automatic analyzer (Poland).

\section{RESULTS AND DISCUSSION}

\section{Laboratory Test Stand}

In order to know the retention capacity of the limestone, that is, the sorption reactivity, experimental tests were carried out for both limestones in the laboratory stand.

From Equations (3) and (4) the values of absolute sorption $C_{i}$, and reactivity index $R_{i}$ were calculated. The sorbent (I) exhibits a high value of $R_{i}$ (around 4.0). According to Table 3 , based on the scale of the reactivity, this limestone belonged to the satisfactory level and then it had low sorption properties. However, sorbent (II) presents a low $\mathrm{R}_{\mathrm{i}}$ value (around 2.5) and thus better sorption properties could be expected.

\section{Industrial Boiler}

'The principal tests were carried out on an industrial scale on fluidized-bed boilers. In order to describe the phenomena associated with combustion-gas desulphurization, the balance of calcium in the combustion chamber as well as the methodology of taking samples and their analysis for fluidized-bed boilers were developed. In addition, the calcium balance enabled the determination of the division of ash into fly ash and bottom ash, combustion-gas desulphurization efficiency as well as the $\mathrm{Ca} / \mathrm{S}$ molar ratio. The tests were carried out on boiler fired brown coal, boilers with a hot cyclone, and a boiler equipped with an external heat exchanger. Seven principal combustion-gas desulphurization tests were carried out with different sorbents and in different systems of sorbent fed into the fluidized-bed boiler chamber. The tests were carried out with the use of limestone sorbents of either low or very good sorption properties determined in laboratory tests.

\section{Flue gas desulphurization with limestone of low sorption properties} (sorbent I)

The industrial test lasted 5 days, in which time the boiler operated under a constant load (100\%). A sufficient quality sorbent was used for desulphurization, as per the specifications given above in Table 1.

Following the adopted methodology described previously, the basic parameters of flue gas desulphurization were determined. The resulting relationship of the sorbent stream with the sulphur content of fuel is represented in Figure 3a. With the increase of the amount of sulphur in the fuel, the sorbent stream increases, as should be expected. The sorbent quality during the tests was invariable, and the desulphurization process was only determined by the sulphur content of fuel. This statement is confirmed by the results of testing of the reactivity index and the conversion degree, which are given in Table 5.

The sorption properties of the sorbent were at a comparable level during the tests, with the difference between individual samples being less than $2 \%$, although the sorbent used was only of sufficient quality, as per Ahlstrom Pyropower Development Laboratory's classification.
The increase in fuel sulphur content causes an increase in the degree of sorbent utilization in the combustion chamber (Figure 3b). There is also consistence here with the authors' laboratory tests, according to which the increase in the sulphur dioxide concentration caused an increase in the degree of conversion.

Figure 3c, in turn, shows the dependence of the $\mathrm{Ca} / \mathrm{S}$ molar ratio on the fuel sulphur content. The straight line obtained from interpolation is parallel to the axis of abscissae. In the correctly conducted flue gas desulphurization process and with the unchanging sorption properties of the sorbent, this is the course of the line that can be expected. When analyzing the data for both limestones in Tables 5 and 6 , it can be noticed that the $\mathrm{Ca} / \mathrm{S}$ molar ratio is closely dependent on the sorption properties. However, with the limestone of low sorption properties, the obtained values of $\mathrm{Ca} / \mathrm{S}$ are overestimated by more than five times relative to the design assumptions and thus no variation can be noticed.

The graph of flue gas desulphurization as a function of $\mathrm{Ca} / \mathrm{S}$ molar ratio (Figure $3 \mathrm{~d}$ ) shows that the line representing the variation is flat and, in the $\mathrm{Ca} / \mathrm{S}$ range from 6 to 10, it coincides with the design line. Beyond this range, no increase in flue gas desulphurization is observed with increasing $\mathrm{Ca} / \mathrm{S}$ molar ratio. Most measurement points lie in the flue gas desulphurization efficiency range of $90-93 \%$, with $\mathrm{Ca} / \mathrm{S}$ ranging from 5 to 18 . In the trial, flue gas desulphurization efficiencies consistent with the design assumptions were successfully achieved, and the boiler maintained the present $\mathrm{SO}_{2}$ emission levels. However, the amounts of limestone (sorbent I) used for flue gas desulphurization were unsatisfactory. The excessive $\mathrm{Ca} / \mathrm{S}$ molar ratios are associated with the excessive limestone streams. The only cause of this was the low sorption properties of the sorbents. With such sorbents, high flue gas desulphurization efficiencies can only be obtained at the cost of excessive limestone streams. According to the design curve, the majority of $\mathrm{Ca} / \mathrm{S}$ measurement points should lie in the range of up to 6.

\section{Flue gas desulphurization with travertine of very good sorption properties (sorbent II)}

The studies involved tests using travertine (sorbent II) whose composition is presented in Table 1 . As in the case before, the calcium balance was made. Figure 4a illustrates the effect of fuel sulphur content on the sorbent stream. A reverse dependence of the sorbent stream on the sulphur content can be seen. With the increase in fuel sulphur content, the sorbent stream decreases. The only reason for that might be the improving sorption properties of the limestone with the time. That fact was in agreement with the results of reactivity index $R_{i}$ tests given in Table 6 .

From the analysis of the reactivity index, it is found that in all test cases the Ri was below 3.0, so the boiler manufacturers' requirements were met. The fuel sulphur content during all of the three test days was, as for industrial conditions, stable and contained in the range from $0.28 \%$ to $0.35 \%$. As the stream of the sorbent increased, the content of sulphur in the fuel decreased. It resulted from very good sorption properties of the sorbent. Noteworthy is the magnitude of the sorbent stream that is more than twice as small compared to the sorbents of low sorption properties, at the same fuel sulphur content level.

In Figure $4 \mathrm{~b}$, variation in the sorbent utilization degree and fuel sulphur content in the duration of the test is shown. This relationship repeats itself for all tests carried out, and the sorbent utilization degree increases with increasing fuel sulphur content. The achieved sorbent utilization degrees are very high. They are more than $3 \times$ higher than for the sorbents with $R_{i}$ above 4.0. 

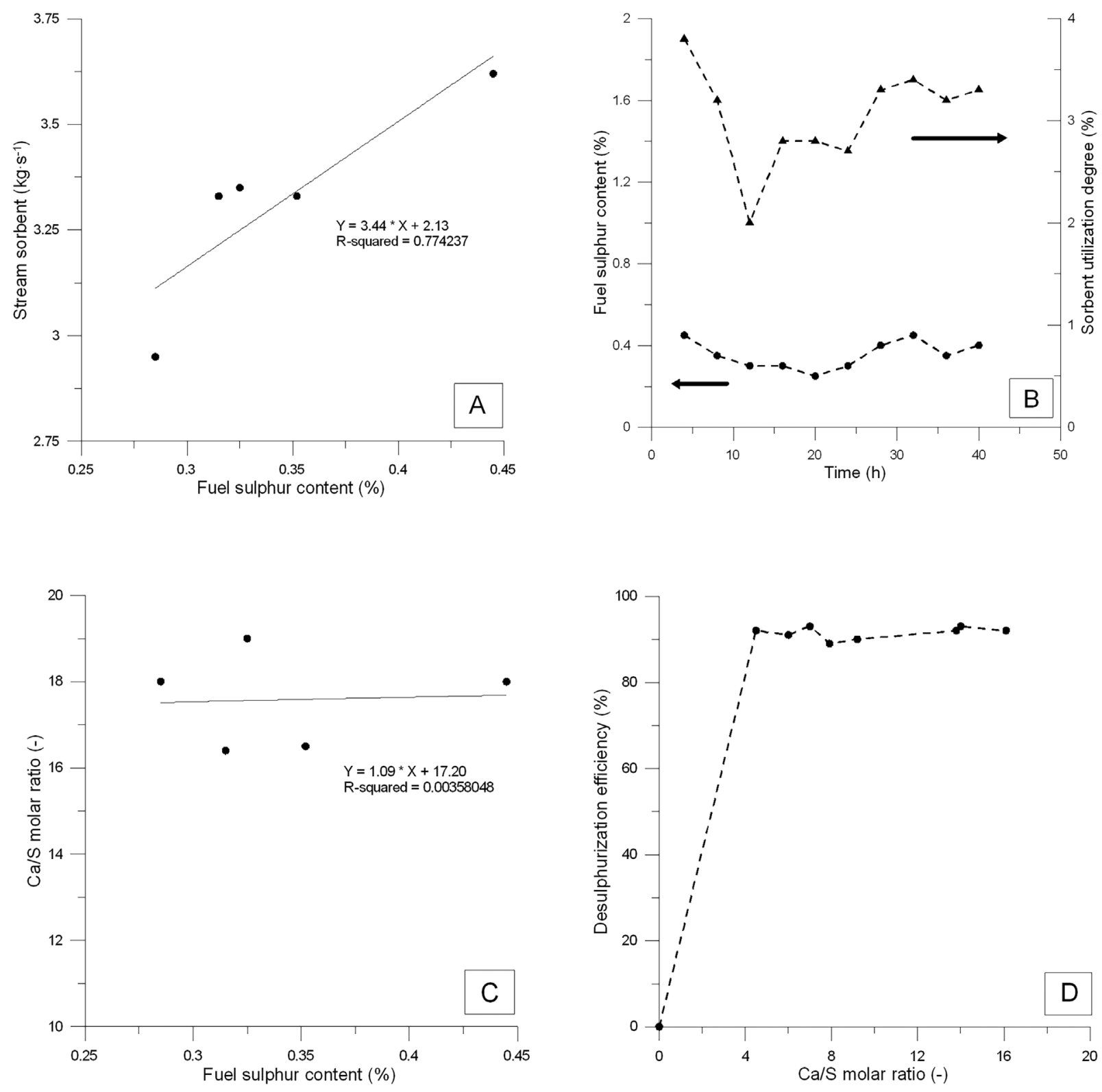

Figure 3. Parameters of flue gas desulphurization with limestone (sorbent I).

Figure $4 \mathrm{c}$ illustrates the effect of the sorbent stream on the sorbent utilization degree. The obtained result is extremely clear, so there was no need for interpolation. The sorbent utilization degree increases with decreasing sorbent stream; obviously, this result needs to be considered jointly with the result given in Table 6. It clearly illustrates the relationship between the reactivity index, the sorbent utilization degree, and the amount of sorbent fed to the combustion chamber. With the improvement in

Table 5. Reactivity index and conversion degree during the test with sorbent I

\begin{tabular}{lcccccccccc}
\hline Sorbent I test $4 \mathrm{~h}$ average & 1 & 2 & 3 & 4 & 5 & 6 & 7 & 8 & 9 \\
\hline $\mathrm{R}_{\mathrm{i}}\left(\mathrm{kmol} \cdot \mathrm{kmol}^{-1}\right)$ & 4.05 & 4.12 & 4.06 & 4.16 & 4.09 & 4.11 & 4.09 & 4.12 & 4.01 & 4.01 \\
$\mathrm{X}(\%)$ & 24.7 & 24.3 & 24.6 & 24.0 & 24.5 & 24.1 & 24.5 & 24.3 & 24.1 & 24.1 \\
\hline
\end{tabular}

\begin{tabular}{lcccccc}
\multicolumn{4}{l}{ Table 6. Reactivity index and conversion degree during the test with sorbent II } & & & \\
\hline Sorbent II test 4 $\mathrm{h}$ average & 1 & 2 & 3 & 4 & 5 \\
\hline $\mathrm{R}_{\mathrm{i}}\left(\mathrm{kmol} \cdot \mathrm{kmol}^{-1}\right)$ & 2.84 & 2.80 & 2.65 & 2.58 & 2.57 \\
$\mathrm{X}(\%)$ & 36 & 35 & 38 & 39 & 39 \\
\hline
\end{tabular}



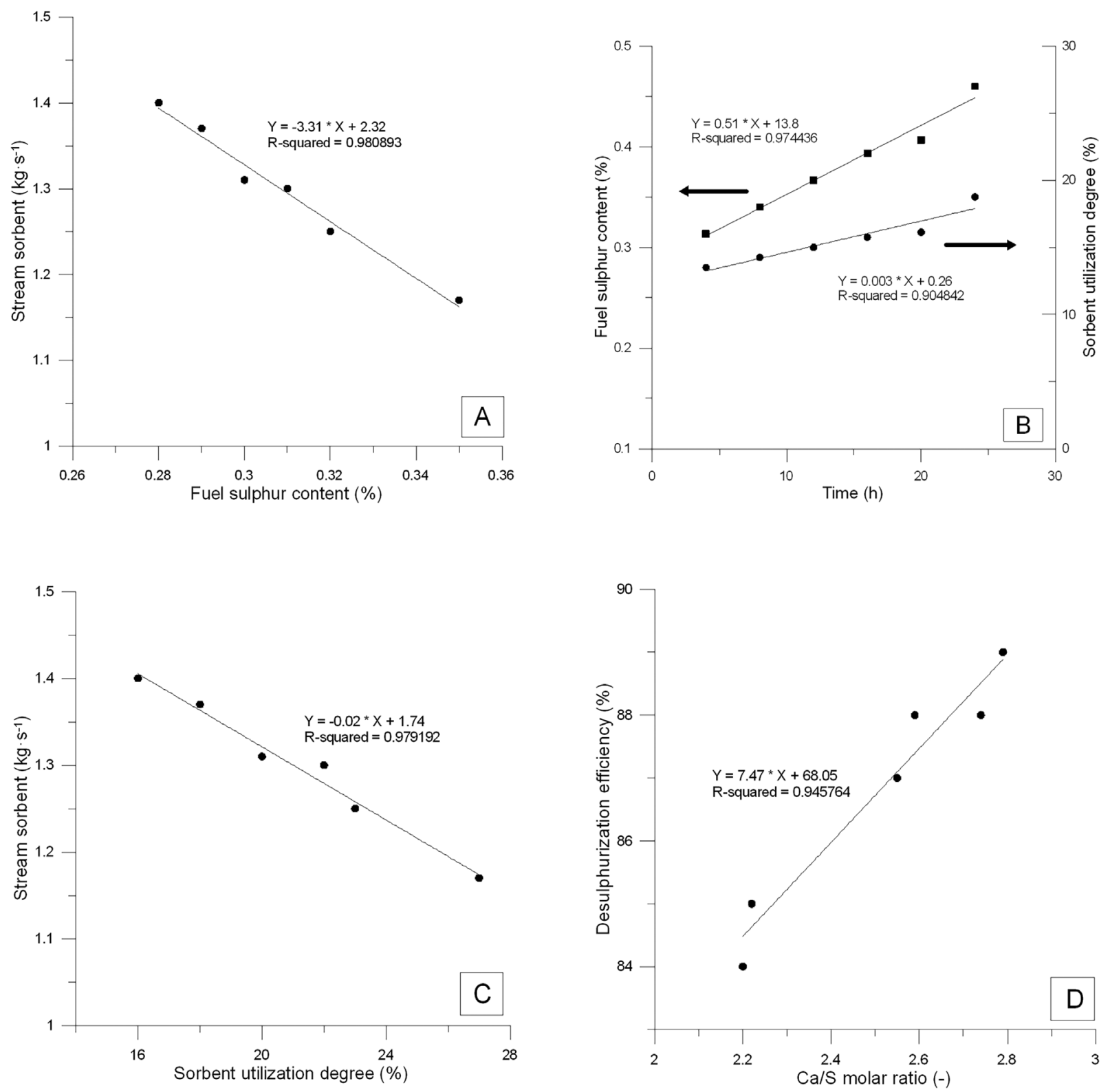

Figure 4. Parameters of flue gas desulphurization with travertine (sorbent II).

sorption properties (the change of Ri from 2.84 to 2.52), we observe an improvement in sorbent utilization from 16 to $27 \%$. At the same time, with increasing sorbent utilization degree, the amount of sorbent to be fed into the combustion chamber in order to desulphurize the flue gas from 1.4 to $1.16 \mathrm{~kg} \cdot \mathrm{s}^{-1}$ decreases.

Using sorbents of high sorption properties allows good effectiveness in flue gas desulphurization. When comparing the results for flue gas desulphurization efficiency as a function of $\mathrm{Ca} / \mathrm{S}$ with the design assumptions (Figure $4 \mathrm{~d}$ ), it can be seen that using sorbents of $R_{i}$ below 3.0 produces better effects than those resulting from the design assumptions. A desulphurization efficiency of $85 \%$ was achieved at $\mathrm{Ca} / \mathrm{S}$ equal to 2.23 , whereas from the design assumptions it follows that this desulphurization efficiency could be achieved at $\mathrm{Ca} / \mathrm{S}$ equal to 3 . Achieving high fuel gas desulphurization efficiencies with small limestone amounts depends mainly on the quality of the sorbent. Therefore, upon the analysis carried out it can be stated that the knowledge of the reactivity index of a given sorbent allows a preliminary evaluation of the desulphurization effectiveness.

Figure 5 summarizes the effect of reactivity factor on the degree of sorbent utilization in the combustion chamber. The behaviour of the interpolation curve clearly informs of the effects of using different quality sorbents. It can be seen that changing the reactivity index from 3.2 to 2.5 results in a more than $2 \times$ increase in the degree of sorbent utilization for flue gas desulphurization.

Similarly, the dependence of the sorbent stream on the reactivity index is shown in Figure 6. Looking at the course of the interpolation curve it can be seen that a slight reactivity index increase from 2.5 to 3.2 results in a $2 \times$ increase in the sorbent stream. Using sorbent I of the reactivity index 4.0 (good sorption properties according to Ahlstrom classification) the stream of the sorbent is actually $1.5 \times$ higher as compared to the sorbent II of the reactivity index 2.5 . 


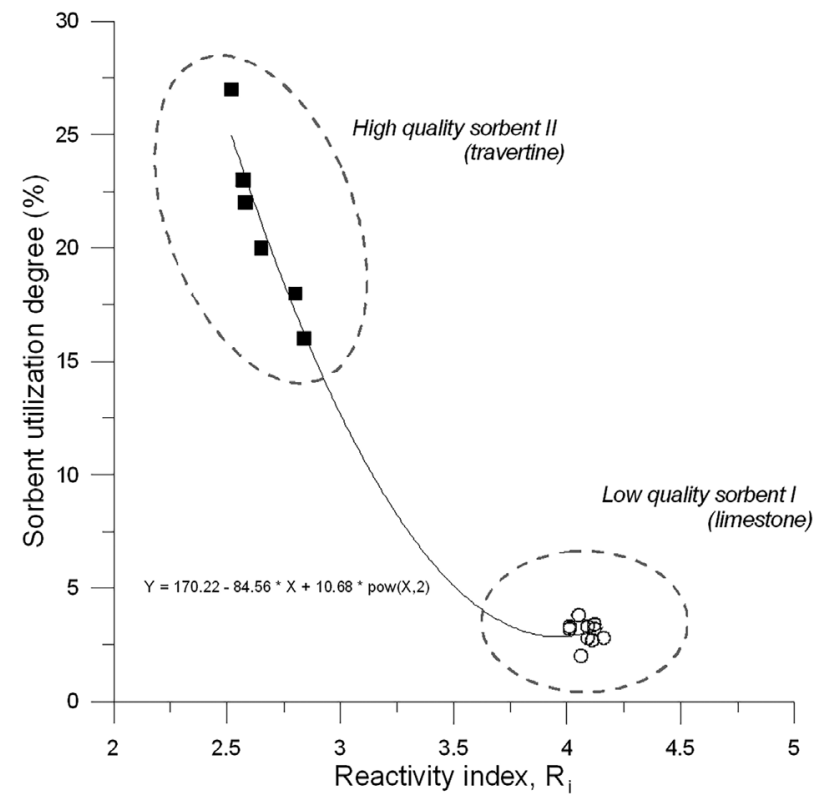

Figure 5. Dependence of the sorbent utilization degree on the reactivity index Ri.

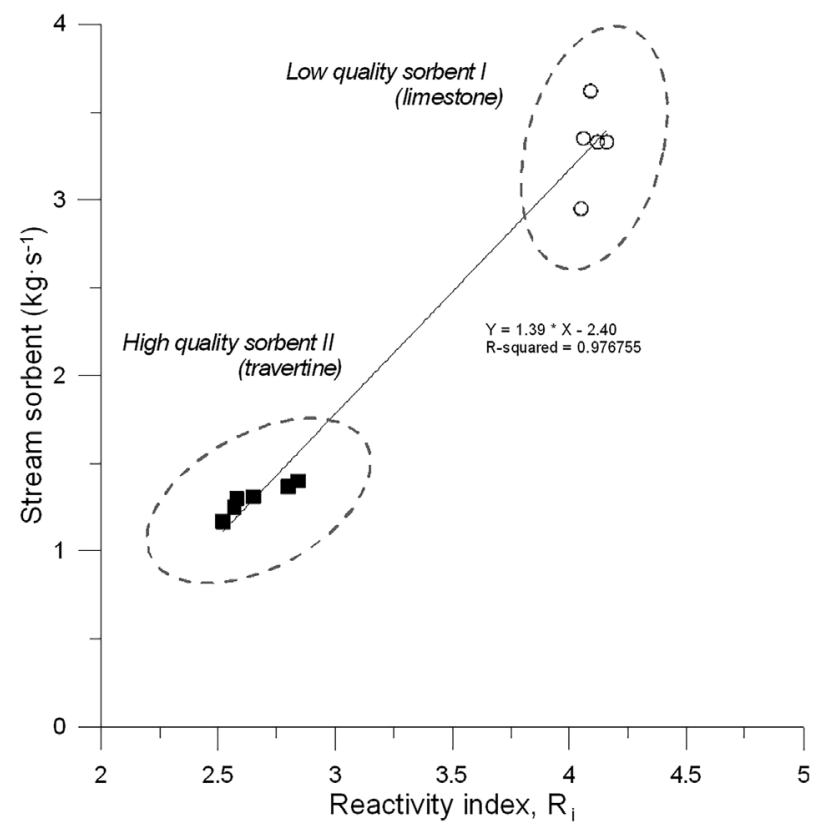

Figure 6. Dependence of the sorbent stream on the reactivity index Ri.

\section{CONCLUSIONS}

From the tests carried out with classic sorbents with the reactivity index equal to approximately 4 , it turned out that the sorbent utilization degree was $5 \%$ on average, which resulted in an increase in the stream of sorbent needed for flue gas desulphurization by 3.5 times. However, the required sulphur dioxide emission levels could be successfully met with a relatively high flue gas desulphurization efficiency of approximately $90 \%$.

The flue gas desulphurization tests have demonstrated that the currently used limestones have highly varying sorption properties, which determines the flue gas desulphurization quality. A crucial effect on the flue gas desulphurization is shown by the

index of reactivity, Ri. According to its definition, the reactivity index takes into account: limestone purity, initial limestone sulphur content, the amount of sulphur bonded in the desulphurization process, fraction composition, as well as calcination temperature which proved to be a very important factor.

It can be established that it is incorrect to conduct flue gas desulphurization using sorbents with $\mathrm{Ri}$ higher than 3.5. Only through an initial selection made by the use of the reactivity index can the efficiency of desulphurization of flue gases be estimated.

\section{ACKNOWLEDGEMENTS}

This research has been supported by the Spanish Ministry of Science and Innovation (MICINN, Project: CTQ2008-05399/PPQ) and by FEDER. M. de las Obras-Loscertales thanks MICINN for the F.P.I. fellowship.

\section{NOMENCLATURE}

$C_{i} \quad$ coefficient of absolute sorption

$c_{o} \quad$ initial $\mathrm{SO}_{2}$ concentration in the model gas $\mathrm{CSO}_{2}$

$c_{t} \mathrm{SO}_{2}$

$\mathrm{C}_{\mathrm{TSO}_{2}}$

$x_{C a}, x_{C_{p}}, x_{S_{p}}$,

$x_{C_{b}}, x_{S_{b}}$ mixture $\left(\mathrm{kmol} \cdot \mathrm{m}^{-3}\right)$

average $\mathrm{SO}_{2}$ concentration in the flue gas $\left(\mathrm{mg} \cdot \mathrm{m}^{-3}\right)$

concentration in time $t\left(\mathrm{kmol} \cdot \mathrm{m}^{-3}\right)$

calculated $\mathrm{SO}_{2}$ concentration $\left(\mathrm{mg} \cdot \mathrm{m}^{-3}\right)$

percentage share of calcium in the sorbent, carbon in the sorbent after the sulphurization process, sulphur after the sulphurization process, carbon before the sulphurization process, and sulphur before the sulphurization process respectively (\%)

$m_{C a_{\text {Fed }}}, m_{C a_{\text {Rem }}}$ stream of calcium fed to the boiler, removed from the boiler respectively $\left(\mathrm{kg} \cdot \mathrm{s}^{-1}\right)$

$m_{F}, m_{\text {Sorb }} \quad$ stream of fuel, sorbent respectively $\left(\mathrm{kg} \cdot \mathrm{s}^{-1}\right)$

$m_{A_{\text {Fed }}}, m_{A_{\text {Rem }}} \quad$ stream of ash fed to the boiler, ash removed from the boiler respectively $\left(\mathrm{kg} \cdot \mathrm{s}^{-1}\right)$

$m_{F A}, m_{B A}$, stream of fly ash, bottom ash, ash in the fuel, $m_{A_{F}}, m_{A_{C+S}} \quad$ ash from incomplete combustion of coal/ sulphur respectively $\left(\mathrm{kg} \cdot \mathrm{s}^{-1}\right)$

$M_{S}, M_{C a}, M_{C}$, molar mass of sulphur, calcium, carbon, carbon $M_{\mathrm{CO}_{2}}, M_{\mathrm{SO}_{2}} \quad$ dioxide, sulphur dioxide $\left(\mathrm{kg} \cdot \mathrm{kmol}^{-1}\right)$

$P$

$R$

$R_{i}$

$S$

$\mathrm{Ca}$

\section{$C a_{T}$}

$T$

$t$

$w$

$V_{s}$

\section{$X$}

$\eta$

$\gamma_{\mathrm{Ca}_{\mathrm{F}}}, \gamma_{\mathrm{CaO}_{F}}$

$\gamma_{S_{F}}$

$\gamma_{C a_{F}}, \gamma_{C a_{S o r b}}$ pressure in the reactor $(\mathrm{Pa})$ gas constant $\left(\mathrm{Pa} \cdot \mathrm{m}^{3} \cdot \mathrm{kmol}^{-1} \cdot \mathrm{K}^{-1}\right)$ reactivity index sulphur content $\left(\mathrm{kg} \cdot \mathrm{s}^{-1}\right)$ content of the calcium taking part in the desulphurization process $\left(\mathrm{kg} \cdot \mathrm{s}^{-1}\right)$

content of the total calcium introduced into the boiler $\left(\mathrm{kg} \cdot \mathrm{s}^{-1}\right)$

temperature $(\mathrm{K})$

reaction time $(\mathrm{s})$

number of calcium moles fed to the reactor (kmol)

molar velocity of gas flowing through the reactor $\left(\mathrm{kmol} \cdot \mathrm{s}^{-1}\right)$

molar Ca conversion degree (\%)

efficiency of the sulphur bonding process

share of calcium in the fuel, calcium oxide in the fuel, sulphur in the fuel respectively $\left(\mathrm{kg} \cdot \mathrm{kg}^{-1}\right)$

share of calcium in the sorbent, in the fly ash, in 
$\gamma_{C a_{F A}}, \gamma_{C a_{B A}}$

$\gamma_{\mathrm{CaCO}_{3 \text { Sorb }}}$,

$\gamma_{\mathrm{CaO}}$ Sorb

\section{REFERENCES}

the bottom ash respectively $\left(\mathrm{kg} \cdot \mathrm{kg}^{-1}\right)$ share of calcium carbonate in the sorbent, calcium oxide in the sorbent respectively $\left(\mathrm{kg} \cdot \mathrm{kg}^{-1}\right)$

[1] L. Lundberg, R. Johansson, D. Pallarès, H. Thunman, Fuel 2017, 197, 42.

[2] H. I. Mathekga, B. O. Oboirien, B. C. North, Int. J. Energ. Res. 2016, 40(7), 878.

[3] G. M. F. Gomes, C. Philipssen, E. K. Bard, G. Souza, Braz. J. Chem. Eng. 2016, 33(02), 319.

[4] B. Leckner, P. Szentannai, F. Winter, Fuel 2011, 90(10), 2951.

[5] M. R. Parise, P. R. G. Kurka, O. P. Taranto, Braz. J. Chem. Eng. 2009, 26, 3.

[6] T. Shimizu, M. Peglow, S. Sakuno, N. Misawa, N. Suzuki, H. Ueda, H. Sasatsu, H. Gotou, Chem. Eng. Sci. 2001, 56, 6719.

[7] A. Kochel, A. Cieplińska, A. Szymanek, Chem. Process Eng. 2012, 33(2), 255.

[8] F. García-Labiano, A. Rufas, L. F. de Diego, M. de las ObrasLoscertales, A. Abad, P. Gayán, J. Adánez, Fuel 2011, 90, 3100.

[9] J. Adánez, F. García Labiano, Thermochim. Acta 1993, 217, 99.

[10] L. F. de Diego, M. de las Obras-Loscertales, F. GarcíaLabiano, A. Rufas, A. Abad, P. Gayán, J. Adánez, Int. J. Greenh. Gas Con. 2011, 5, 1190.

[11] J. Adánez, F. García Labiano, J. C. Abanades, L. F. de Diego, Fuel 1994, 7(3), 355.

[12] B. Walawska, A. Pajdak, Przem. Chem. 2016, 95(6), 1181.

[13] S. R. Bragança, J. L. Castellan, Braz. J. Chem. Eng. 2009, 26, 2.

[14] T. Shimizu, M. Peglow, S. Sakuno, N. Misawa, N. Suzuki, H. Ueda, H. Sasatsu, H. Gotou, Chem. Eng. Sci. 2002, 57, 4117.

[15] K. M. Sellakumar, J. Isaksson, J. Tiesuu, "Process Performance of Ahlstrom Pyroflow PCFB Pilot Plant," 12th International Conference on fluidized Bed Combustion, Electric Power Research Institute, American Society of Mechanical Engineers, San Diego, 8-13 May 1993.

[16] A. Szymanek, The flue gas desulphurisation using mechanically activated lime waste, Monograph 51, Publishing House of Wrocław University of Science and Technology, Wrocław 2008.

[17] A. Szymanek, W. Nowak, Chem. Process Eng. 2007, 28, 127.

[18] A. Szymanek, W. Nowak, Chem. Process Eng. 2007, 28, 259.

[19] A. Szymanek, A. Kochel, A. Cieplińska, Chem. Process Eng. 2012, 33(2), 255.

[20] A. Szymanek, A. Kochel, A. Cieplińska, Chem. Process Eng. 2012, 33(3), 359.

[21] A. Kochel, A. Cieplińska, A. Szymanek, Energ. Fuel. 2015, $29(1), 331$.

[22] A. Szymanek, Inżynieria i Ochrona Środowiska 2009, 11(4), 417.

[23] A. Szymanek, Ochrona powietrza i problemy odpadów 2005, 1,7 .

[24] A. Szymanek, Ochrona powietrza i problemy odpadów 2005, 4, 117.
[25] A. Szymanek, Ochrona powietrza i problemy odpadów 2005, 6, 199.

[26] A. Szymanek, Inżynieria i Ochrona Środowiska 2006, 9(3), 273.

[27] Polish Committee for Standardization, Solid fuels - Determination of volatile matter by the gravimetric method, PN-G04516, PKN, Warsaw 1998.

[28] Polish Committee for Standardization, Solid fuels - Determination of ash content by the gravimetric method, PN-G-04512, PKN, Warsaw 2002.

[29] B. Walawska, A. Szymanek, A. Pajdak, M. Nowak, Pol. J. Chem. Technol. 2014, 16(3), 56.

[30] Polish Committee for Standardization, Chemical analysis Limestone, burnt lime and hydrated lime, PN-B-04350, PKN, Warsaw 1976.

[31] A. Kochel, A. Cieplińska, A. Szymanek, Chem. Process Eng. 2012, 33(3), 359.

[32] T. Czakiert, K. Sztekler, S. Karski, D. Markiewicz, W. Nowak, Fuel Process. Technol. 2010, 91, 1617.

[33] Polish Committee for Standardization, Limestone and burnt lime and hydrated lime, PN-B-04350, PKN, Warsaw 2010.

[34] Polish Committee for Standardization, Solid fuels - Determination of the chemical composition of ash. Determination of the calcium oxide content, PN-G -04528-06, PKN, Warsaw 2010.

[35] Polish Committee for Standardization, Solid fuels - Determination of moisture content, PN-G-04511, PKN, Warsaw 2010.

[36] Polish Committee for Standardization, Solid fuels - Determination of the heat of combustion and calculation of the calorific value, PN-G-04513, PKN, Warsaw 1981.

[37] Polish Committee for Standardization, Methods of testing of natural stone - Compressive strength determination, PN-EN 1926:2007, PKN, Warsaw 2007.

[38] Polish Committee for Standardization, Solid fuels Determination of the carbon and hydrogen contents by the Sheffield method, PN-G-04521, PKN, Warsaw 1973.

[39] Polish Committee for Standardization, Solid fuels - Determination of the nitrogen content by the Kiejdahl method, PN-G04523, PKN, Warsaw 1992.

[40] Polish Committee for Standardization, Solid fuels - Determination of overall and ash sulphur contents using automatic analyzers, PN-G-04584, PKN, Warsaw 2001.

Manuscript received April 11, 2017; revised manuscript received July 20, 2017; accepted for publication July 22, 2017. 